\title{
Article
}

\section{PROBIOTICS FOR TREATMENT OF CHRONIC CONSTIPATION IN CHILDREN: A COCHRANE SYSTEMATIC REVIEW}

\author{
Gordon, Morris
}

Available at https://clok.uclan.ac.uk/14909/

Gordon, Morris orcid iconORCID: 0000-0002-1216-5158 (2016) PROBIOTICS FOR TREATMENT OF CHRONIC CONSTIPATION IN CHILDREN: A COCHRANE SYSTEMATIC REVIEW. Archives of Disease in Childhood, 101 (Supp 1). A25. ISSN 0003-9888

It is advisable to refer to the publisher's version if you intend to cite from the work.

For more information about UCLan's research in this area go to http://www.uclan.ac.uk/researchgroups/ and search for <name of research Group>.

For information about Research generally at UCLan please go to http://www.uclan.ac.uk/research/

All outputs in CLoK are protected by Intellectual Property Rights law, including Copyright law. Copyright, IPR and Moral Rights for the works on this site are retained by the individual authors and/or other copyright owners. Terms and conditions for use of this material are defined in the policies page.

\section{CLoK}

Central Lancashire online Knowledge www.clok.uclan.ac.uk

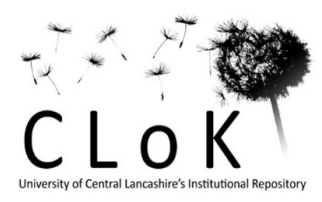


CONTROL ID: 2433735

CURRENT CATEGORY: Clinical Practice

PRESENTATION TYPE: AGA Institute Oral or Poster

PRESENTER: Morris Gordon

PRESENTER (E-MAIL ONLY): general@biyeeproperties.com

Abstract

TITLE: Probiotics for the management of functional abdominal pain in children: A Cochrane systematic review AUTHORS (LAST NAME, FIRST NAME): Gordon, Morris ${ }^{1,2}{ }^{\text {; Stone, Joe }}{ }^{2}$; Thomas, Adrian ${ }^{3}$; Akobeng, Anthony ${ }^{4}$ INSTITUTIONS (ALL):

1. School of Medicine, University of Central Lancashire, Preston, United Kingdom.

2. Families Division, Blackpool Victoria Hospital, Blackpool, United Kingdom.

3. Royal Manchester Childrens Hospital, Manchester, United Kingdom.

4. Sidra Medical \& Research Center, Doha, Qatar.

ABSTRACT BODY:

Abstract Body: Background

Functional abdominal pain is pain located in the abdomen that cannot be explained by visible or detectable abnormalties. It is hypothesised that the use of probiotics might alter the growth of bacteria in the bowel, promote normal gut physiology and reduce functional symptoms. Given the recent growth in published studies in this area it is necessary to produce a new and focussed synthesis of this evidence by deploying a robust methodology to ensure that there can be a contemporaneous impact on clinical practice.

\section{Methods}

The Cochrane Central Register of Controlled Trials, MEDLINE, EMBASE, CINAHL and Cochrane Inflammatory Bowel Disease \& Functional Bowel Disorders Group Specialised Trial Register were searched (Inception - July 2015). Manufacturers of probiotics were contacted to identify unpublished trials. References of trials were also searched. Abstracts were considered for inclusion if full details to judge inclusion were offered or available from the authors. Randomised controlled trials (RCTs) that compared probiotics against placebo or any other intervention were eligible for inclusion. Data extraction and assessment of methodological quality of included studies were independently performed by two authors. Analysis was completed in accordance with the intention to treat approach.

\section{Results}

The search yielded 1672 results and nine placebo controlled studies $(n=701)$ met the inclusion criteria, two as abstracts and seven as published studies. Three studied Lactobacillus GG, three lactobacillus reuteri, one VSL\#3, one bacillus coagulans and one bifidobacteria. The studies ranged in length from 4 to 16 weeks. The risk of bias was low for randomisation for seven trials and moderate for two trials. Allocation concealment was low in two studies and unclear in the others. All studies were double blinded, but only four gave details of how this was achieved. The risk of bias was low or unclear in all studies for incomplete outcome data and selective reporting. Meta-analysis of seven studies $(n=541)$ found a statistical significant reduction in the severity of pain using probiotics compared to placebo (MD -0.32; $95 \% \mathrm{Cl}-0.38$ to -0.25$)$. Meta-analysis of four studies $(n=440)$ found a statistical significant difference in patients reaching treatment success favouring probiotics compared to placebo (OR 1.80; $95 \% \mathrm{Cl} 1.20$ to 2.69). Metaanalysis of five studies $(n=385)$ found no statistical significant difference in adverse events between probiotics and placebo (OR $0.00 ; 95 \% \mathrm{Cl}-0.07$ to 0.06 ).

\section{Conclusions}

The evidence from the published suggests superior efficacy of probiotics for functional abdominal pain in children when compared with placebo. There is no difference in adverse events, suggesting safety. The evidence base is of moderate quality and relatively small. Further research to investigate the long term impact of probiotic therapy is suggested. 
(no table selected) 
Probiotics Placebo Mean Difference Mean Difference

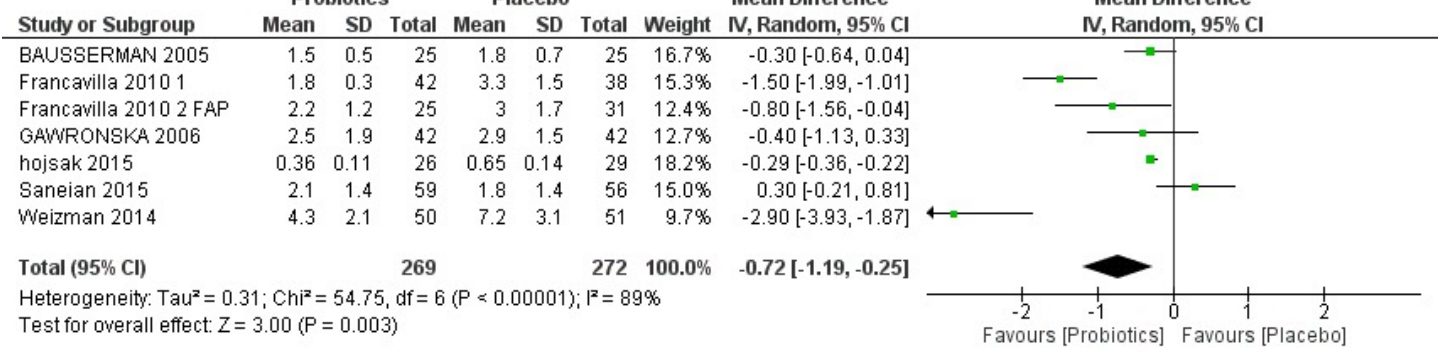

Figure 1: Forest plot of severity of pain, Probiotics vs Placebo 
Probiotics Placebo Risk Difference

Risk Difference

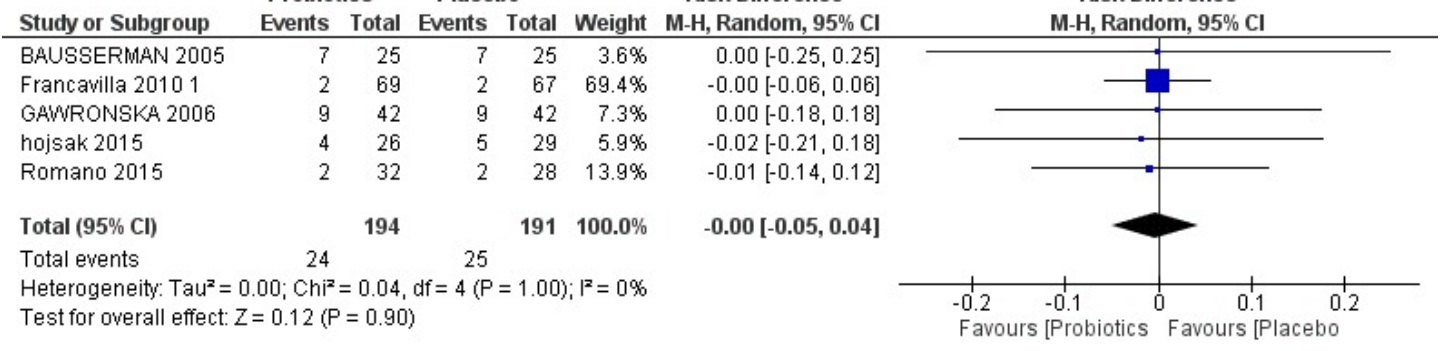

Forest plot of Adverse events, Probiotics vs Placebo 


\section{Disclosure Status}

The following authors have completed their 2016 DDW disclosure:: Morris Gordon: Disclosure completed | Joe Stone: No Answer. | Adrian Thomas: No Answer. | Anthony Akobeng: No Answer. 